\title{
Jerusalem artichoke (Helianthus tuberosus L.): A review of in vivo and in vitro propagation
}

\author{
Alla, N. A., ${ }^{1,2}$ " Domokos-Szabolcsy, É., ${ }^{2}$ El-Ramady, H., ${ }^{2,3}$ Hodossi, S., ${ }^{4}$ Fári, M., ${ }^{2}$ \\ Ragab, M. ${ }^{5}$ \& Taha H. ${ }^{1}$ \\ ${ }^{1}$ Plant Biotechnology Dept., Genetic Engineering Div., National Research center, 33-El-Behouth St., \\ 12622 Dokki,Cairo,Egypt (E-mail:neama_ncr@yahoo.com and hussein.taha2@yahoo.com) \\ ${ }^{2}$ Agricultural Botanics, Plant Physiology and Biotechnology Dept., Debrecen Uni., AGTC \\ Böszörményi utca. 138, 4032 Debrecen, Hungary \\ (E-mail:domokosszabolcsy@gmail.com and fari@agr.unideb.hu) \\ ${ }^{3}$ Soil and Water Sciences Dept., Faculty of Agriculture, Kafrelsheikh Uni., 33516 Kafr El-Sheikh, Egypt \\ ${ }^{4}$ Institute of Research and Development, Center of Agricultural Sciences, Debrecen Uni., \\ Böszörményi utca. 138, 4032 Debrecen, Hungary (E-mail: mtkdakania@agr.unideb.hu) \\ ${ }^{5}$ Horticultural Sciences Dept., Faculty of Agriculture, Ain Shams University, Egypt
}

\begin{abstract}
Summary: Jerusalem artichoke (Helianthus tuberosus L.) is an old tuber crop with a recently renewed interest in multipurpose improvement. It is a perennial tuberous plant rich in inulin and is a potential energy crop. During food shortages in times of war Jerusalem artichoke received more attention by scientists and farmers because of its multiple uses as a vegetable, medicinal plant, forage plant and source for biofuel. The energy crisis of the 1970s motivated research on Jerusalem artichoke for biofuel as the aboveground plant biomass and the tubers can be used for this purpose. There are different methods to propagate Jerusalem artichoke using tubers, rhizomes, slips (transplants derived from sprouted tubers), stem cuttings, seeds and tissue culture. So, this review was presented to highlight on propagation of Jerusalem artichoke via in vivo and in vitro techniques.
\end{abstract}

Keywords: Jerusalem artichoke, in vitro propagation, tuber, somatic embryogenesis

\section{Introduction}

Jerusalem artichoke) Helianthus tuberosus), which is also called sunchoke, sunroot, topinambur or earth apple, is a perennial species belongs to Asterceae family, native to eastern North America, closely related to the sunflower.. Known for its tubers rich in inulin (Monti et al. 2005; Tassoni et al. 2010). Inulin is a polymer of monosaccharide fructose ,.Jerusalem artichoke is a healthy choice for diabetics (typ. 2) , therefore mainly cultivated as a vegetable, but also utilized as fodder crop, and a source of inulin for food and industrial purposes (Kays and Nottingham, 2008b). This plant is among the best crops for inulin production. The tubers are seldom bothered by insects and diseases ( Splittstoesser, 1990 ). The inulin used as diabetics, has a positive effects on blood glucose attenuation, lipid homeostasis, mineral bioavailability and immunomodulation effects. Inulin and other polyfructosides are mainly used for the production of high-fructose syrups and artificial sweeteners in food industries. Along with the ability to add texture and improve rheological characteristics and nutritional properties of food allows inulin to be termed a functional food. It can also preferentially stimulate the growth and activity of one or a limited number of desired bacteria in the colon, and thus improves host health. These beneficial microorganisms, such as Lactobacilli and bifidobacteria, in food are known as probiotics (Gibson et al. 1995; Gallaher and Schneeman, 1996). Adding inulin to fermented milk could promote growth and provide protection of Lactobacillus salivarius during cold storage. As well inulin improved the viability of L. salivarius Alani et al. (2009). Furthermore, inulin of Jerusalem artichoke is used as non-food application in the manufacture of biodegradable plastics, cosmetics, and detergents. The tubers of plants can be also considered for succinic acid and butyric acid production (Kays and Nottingham, 2008b). Jerusalem artichoke as plant produces huge green biomass with few inputs, it is considered in silage production (Seiler, 1993).

Moreover, Jerusalem artichoke can be used for bioethanol production and it could potentially also applying for soil remediation via removal of heavy metal pollutants (Chen et al. 2011). Jerusalem artichoke is propagated using tubers, rhizomes, slips (transplants derived from sprouted tubers), stem cuttings, seeds and tissue culture. Tubers represent the primary choice for commercial production of the crop. While rhizomes are important in the regeneration 
of wild populations, rhizomes, slips, and stem cuttings represent secondary methods of asexual propagation that are occasionally used to expand the numbers of a particular clone when tubers are not available. Tissue culture is used for long-term storage of clones in germplasm repositories and for the production of transgenic plants. Unlike sunflower (Helianthus annuus L.), where seed represents the primary means of propagation, seed is not a viable method for the production of Jerusalem artichokes and is used only in breeding programs to obtain the progeny from crosses (Kays and Nottingham, 2008a).

\section{Propagation of Jerusalem artichoke}

Jerusalem artichoke is usually propagated vegetatively, from tubers or tuber pieces. Reproduction by seed, although of no consequence in commercial production, is a means of dispersal for wild populations and is vital when crossing in plant breeding programs. Propagation is also possible from rhizomes, slips, and cuttings. Jerusalem artichoke is amenable to propagation by tissue culture, being a model species used in pioneering micropropagation studies (Kays and Nottingham, 2008c).

\section{In vivo propagation of Jerusalem artichoke}

Jerusalem artichokes are propagated from tubers or tuber pieces typically 45 to $60 \mathrm{~g}$ in size; large tubers can be cut into smaller pieces that sprout under normal conditions as well as intact tubers (Baillarge, 1942; Milord, 1987). Rhizomes are specialized underground stems that arise from belowground portions of the aerial stem. They facilitate dispersal in that they can form new vegetative shoots as far as $50 \mathrm{~cm}$ outward from the parent plant (Swanton, 1986). Furthermore, rhizomes are generally white, vary in length, and have nodes that possess axillary buds from which branches and vegetative shoots may arise. Regeneration of plants via rhizomes is substantially less than that for tubers; however, their reproductive potential is significant and varies depending upon a number of factors (e.g., clone, age, depth in the soil, size, and environmental conditions). Moreover, slips (transplants), derived from sprouted tubers, can be used to increase the plant population of a clone over what would be realized via direct field planting of the tubers. Whereas, stem cuttings can be readily rooted under appropriate conditions (Phillips, 1985; Norcini and Aldrich, 2000). On the other hand seed reproduction is important in wild populations and is an essential part of Jerusalem artichoke plant breeding programs. Jerusalem artichoke is an obligate out crosser that exhibits a high level of self-incompatibility (van de Sande Bakhuyzen and Wittenrood, 1950; Toxopeus, 1991).

\section{In vitro propagation of Jerusalem artichoke}

Plant tissue culture is the culturing of cells, tissues, or organs from plants under aseptic conditions. The material cultured ranges from cells or cell aggregates in suspension to mature or immature embryos, segments, or explants of plant organs, and isolated plant organs, shoot, or root tips. Helianthus species have been raised from diverse material, although Jerusalem artichoke has been predominantly micropropagated through the culturing of tuber tissue explants. Plant tissue culture is an important tool in plant breeding programs and in the conservation of genetic resources. Moreover, tissue culture facilitates the screening of in vitro germplasm for desirable traits, such as Sclerotinia resistance or cold and salt tolerance (Escandon and Hahne, 1991; Cassells and Walsh, 1995). Also, tissue culture enables germplasm of Jerusalem artichoke to be preserved in biodiversity conservation programs.

Jerusalem artichoke can be in vitro propagated efficiently on relatively simple nutrient medium through repeated subcultures. Only one bud of two per node produced a shoot suitable for the obtaining segments for the next subculture. The dominance of one bud over the other has been observed in in vitro propagated plants of other species with two buds at the node such as Dianthus and Theobroma cacao (Esan, 1992). In vitro propagated Jerusalem artichoke can be used as a model for the study of correlative bud inhibition. Moreover, clonal in vitro propagation can be used for prolonged maintenance of Jerusalem artichoke lines and varieties devoid of pathogens. Furthermore, in vitro propagated plantlets provide nodal stem segments for microtuber induction (Gamburg et al. 1999).

- Clonal micropropagation and microtubers induction of Jerusalem artichoke

Clonal micropropagation of Jerusalem artichoke was initiated from axillary meristems of lateral shoots of fieldgrown plants on medium with MS salts, $2 \%$ sucrose, $1 \mathrm{mg}$ $\mathrm{l}^{-1}$ thiamine- $\mathrm{HCl}, 1 \mathrm{mg} \mathrm{l}^{-1}$ IAA and $0.6 \%$ agar. Plantlets were cut into nodal sections and used for subsequent subcultures and for Microtubers induction. Microtubers were induced from axillary meristems on medium with half-strength of MS salts, $8 \%$ sucrose and $0.5 \mathrm{mg} \mathrm{l}^{-1} \mathrm{BA}$ in darkness at $18{ }^{\circ} \mathrm{C}$. They had near to $30 \%$ of dry matter. Microtubers resumed growth in light room at $23{ }^{\circ} \mathrm{C}$ after $4-6$ months of cold storage (Gamburg et al. 1999). Microtubers are the best plant material for germplasm conservation of tuberproducing plants because they are pathogen-free and are suitable for prolonged preservation at low temperature. Potato microtubers are used widely for international exchange of cultivars and germplasm. In vitro tuberization was used to study hormonal regulation of tuber formation (Melis and Van Staden, 1984; Vreugdenhil and Struik, 1989) and tuber protein gene expression (Bourque et al. 1987) and as a simple and effective means of screening potato genotypes capable to form tubers at high temperature (Nowak and Colborne, 1989). Methods for microtuber induction from micropropagated plantlets are established for potato and yam (Dodds et al. 1992; $\mathrm{Ng}, 1992$ ). The study of microtuber formation in Jerusalem artichoke as in other tuber-producing plants may be useful for elucidation of common characteristics of tuberization in plants. However, 
clonal micropropagation of Jerusalem artichoke has not been described and in vitro tuberization was performed only with stem segments excised from intact plants (Wyssmann and Tripathi, 1977; Koda and Kikuta, 1991). The requirements for microtuber induction were similar in Jerusalem artichoke and potato (Dodds et al. 1992). Further work must be done to study the dependence of microtuber formation on light/ dark regime, type of explant, sucrose concentration, type and concentration of cytokinin and incubation temperature. Microtubers can be obtained in Jerusalem artichoke in darkness below $20{ }^{\circ} \mathrm{C}$ on medium with high sucrose ( $8 \%$ may be optimal). High concentration of sucrose was shown to be necessary for microtuber formation in potato with $8 \%$ being optimal level (Garner and Blake, 1989; Dodds et al. $1992)$ and in white yam (Ng, 1992). Cytokinin (BA) (0.5 $\mathrm{mg} \mathrm{l}^{-1}$ being optimal concentration) increased the number of microtubers possibly due to the weakening of correlative growth inhibition of one lateral bud by another. However, microtuber induction was high enough also in the absence of BA, whereas BA did not induce microtubers at $2-4 \%$ sucrose. Thus, BA must be considered as an improving but not an inducing factor in microtuber formation in Jerusalem artichoke (Garner and Blake, 1989).

- Somatic embryogenesis of Jerusalem artichoke

Somatic embryogenesis resulting in regeneration of whole plant is an important step in a plants transformation method. Successful and stable transformation requires mechanism by which a single cell is able to give rise to a plant. Ideal transformation scheme is issued from somatic embryogenesis, as in a callus each transformed cell is able to produce a plant. In vitro morphogenesis and somatic embryogenesis was studied in relation to genetic basis and showed the genetic control of organogenesis. Somatic embryogenesis and subsequent plant regeneration have been reported in most of main major crop species (Evans and Sharp, 1981)

El Mostafa et al. (2008) studied the effect of plant growth regulators on somatic embryogenesis from leaf segment of in vitro cultures of Helianthus tuberosus L. They found that the highest frequency of somatic embryos (41.6) was observed on MS medium supplemented with $0.1 \mathrm{mg} \mathrm{l}^{-1}$ NAA. In the genus Helianthus plant regeneration has been achieved through organogenesis and somatic embryogenesis, whereas, some studies reported a strong correlation between the genetic background of the donor plant and its in vitro regeneration response (Paterson et al. 1985; Pelissier et al. 1990; Knittel et al. 1991; Sarrafi et al. 1996).

- Callus cultures production and plantlet regeneration of Jerusalem artichoke Taha et al. (2007) established a promising protocol of calli production and regenerated shootlets from leaf and nodal stem explants of Jerusalem artichoke. They stated that MS-medium supplemented with $1 \mathrm{mg} \mathrm{L}^{-1}$ each of NAA and BAP gave the best results. However, MS-medium fortified with $0.5 \mathrm{mg} \mathrm{L}^{-1} \mathrm{NAA}+3 \mathrm{mg}$ $\mathrm{L}^{-1} \mathrm{BAP}$ was the best medium for enhancement of shootlets regeneration which gave 55\% and $32 \%$ from stem nodal and leaf calli cultures, respectively.
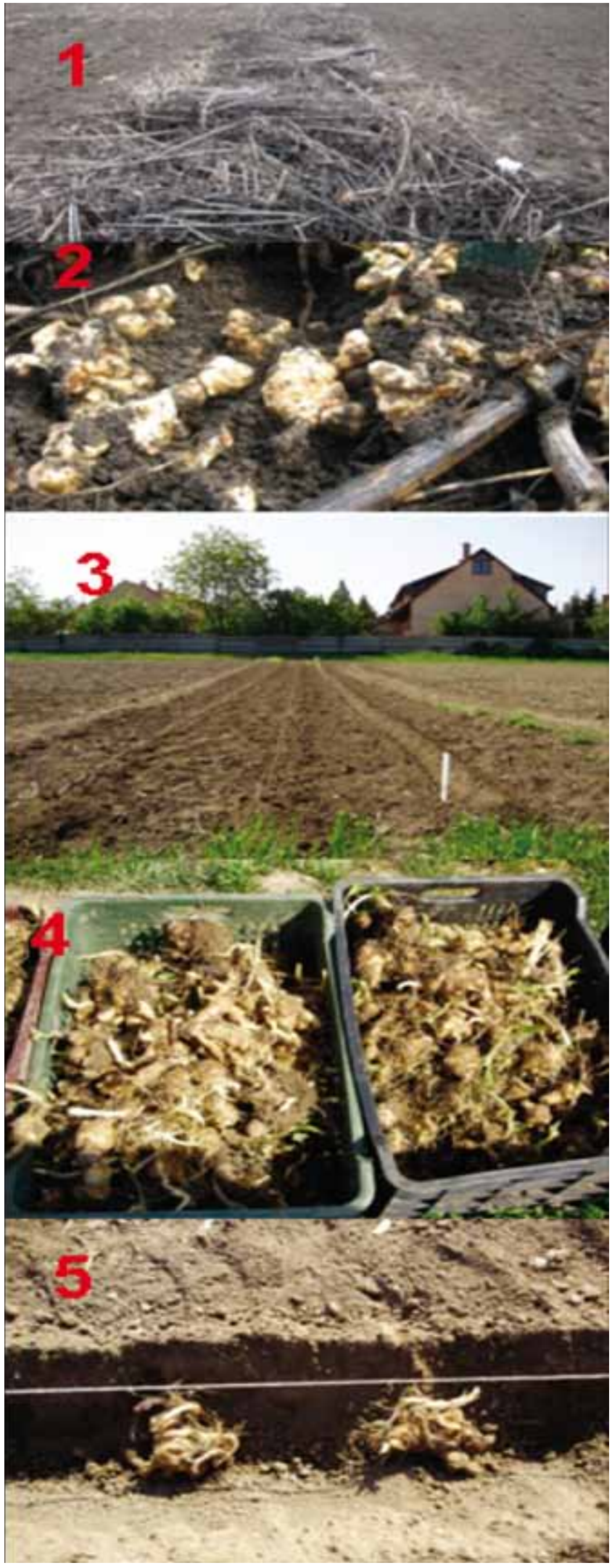

Fig. 1: In vivo propagation of Jerusalem artichoke using tubers: Storing of tubers in the soil during winter season (photos 1 and 2); preparing soil for cultivation (photo 3); sprouted tubers, which cultivated in the field in April (photos 4 and 5) (Photos by N. Abd Alla, Demonstration Garden, Agricultural Botanics, Plant Physiology and Biotechnology Dept., Debrecen Uni., Hungary, 2013-2014) 

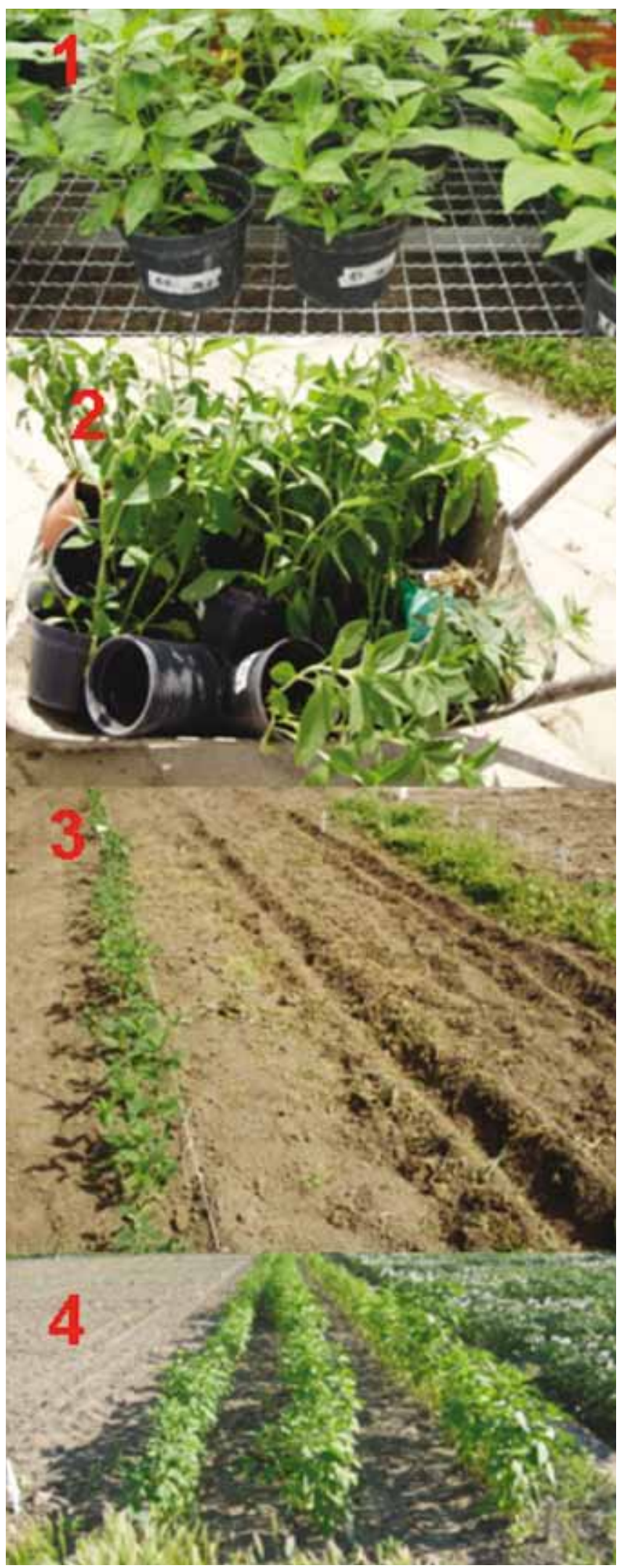

Fig. 2: In vivo propagation of Jerusalem artichoke using transplants: cultivated tubers in pots in green house (photo 1); produced transplants ready for cultivation (photo 2); cultivated transplants in the field (photos 3 and 4) (Photos by N. Abd Alla, Demonstration Garden, Agricultural Botanics, Plant Physiology and Biotechnology Dept., Debrecen Uni., Hungary, 2013-2014)
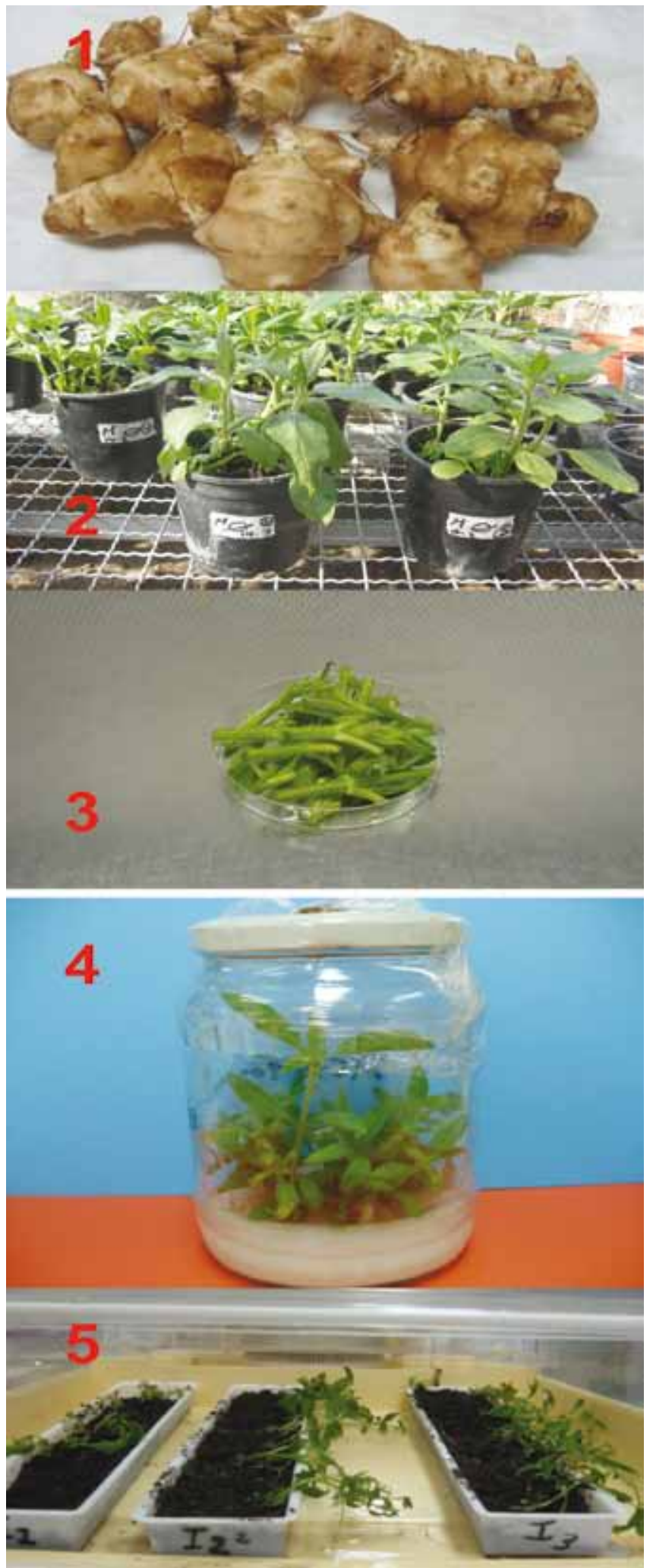

Fig. 3: In vitro propagation of Jerusalem artichoke using stem nods: clean and surface sterilized harvested tubers (photo 1); transplants produced from tubers as a source of stem nod explants (photo 2); disinfected stem nod explants in laminar air flow (photos 3); acclimatization of in vitro plants (on MS medium containing starch, Photo 4) and using micro-farm (Photo 5) (Photos by N. Abd Alla, Demonstration Garden, Agricultural Botanics, Plant Physiology and Biotechnology Dept., Debrecen Uni., Hungary, 2013-2014). 


\section{Conclusion}

It could be summarized that, Jerusalem artichoke can be propagated using in vivo techniques (tubers, rhizomes, slips, stem cuttings, seeds) and in vitro by tissue culture techniques. There are limit literature reviews about in vitro propagation of this important plant and this may be due to some restrictions such as a long period of dormancy (from 4 to 6 months), in vitro vitrification and contamination. Therefore, further studies should be achieved to overcome these previous problems. Moreover, we aim in the future to produce biofortified and tolerant Jerusalem artichoke for human nutrition and soil remediation purposes, respectively.

\section{Acknowledgments}

We would like to express our gratitude to Hungarian Scholarship Board (HSB), Balassi institute, Hungary, for its fund and support.

\section{References}

Alani, S. R., A. M. Fraser, M. A. Alsharafani, F. F. Al-Nouri, and S. A. Ibrahi (2009): The effect of inulin from Jerusalem artichoke (Helianthus tuberosus) extract on growth and viability of Lactobacillus salivarius in fermented milk. [In: G.A. Uzochukwu et al. (eds), Proceedings of the 2007 National Conference on Environmental Science and Technology.] DOI 10.1007/978-0-38788483-7 4, C_ Springer Science+Business Media, LLC.

Baillarge, E. (1942): Le Topinambur: Ses Usages, Sa Culture, Flammarion, Paris.

Bourque, J. E. ; J. C. Miller and W.D. Park (1987): Use of an in vitro tuberization system to study tuber protein gene expression. Vitro Cell. Dev. Biol. 23: 381-386.

Cassells, A. C. and M. Walsh (1995) Screening for Sclerotinia resistance in Helianthus tuberosus L. (Jerusalem artichoke) varieties, lines and somaclones, in the field and in vitro, Plant Pathol., 44: 428-437.

Chen Liang, Long Xiao-Hua, Zhang Zhen-Hua, Zheng Xiao-Tao, Z. RENGEL and Liu Zhao-Pu (2011): Cadmium Accumulation and Translocation in Two Jerusalem Artichoke (Helianthus tuberosus L.) Cultivars. Pedosphere. 21 (5): 573-580.

Dodds, J. H.; D. Silva-Rodrigues and P. Tovar (1992): Micropropagation of potato (Solanum tuberosum L.). [In: Bajaj YPS (ed) Biotechnology in Agriculture and Forestry.] 19: 91-106. Springer Verlag, Berlin.

El Mostafa, N., M. Fakiri, M. Benchekroun, J. Amzil, A. El Arbaoui and S. Hilali (2008): Effect of plant growth regulators on somatic embryogenesis from leaf in vitro cultures of Helianthus tuberosus L. Journal of Food, Agriculture \& Environment, 6 (2): 213-216.

Esan, E. B. (1992): Micropropagation of cocoa (Theobroma cacao L.) In: Bajaj YPS (ed)

Biotechnology in Agriculture and Forestry, 19: 91-106. Springer Verlag, Berlin.
Escandon, A. S and G. Hahne (1991): Genotype and composition of culture medium are factors important in the selection for transformed sunflowers (Helianthus annuus L.) callus, Physiol. Plant., 81: 367-376.

Evans, D. and W. Sharp (1981): Growth and behavior of cell cultures: Embryogenesis and organogenesis. [In Trevor, A.T. (ed.). Plant Tissue Cultures.] Academic Press, New York.

Evans, D. and W. Sharp (1981): Growth and behavior of cell cultures: Embryogenesis and organogenesis. [In Trevor, A.T. (ed.). Plant Tissue Cultures. ]Academic Press, New York.

Gallaher, D. D. and B. O. Schneeman (1996): Dietary-fiber. [In: present knowledge in nutrition.] (Ziegler, E. E \& Filer, L. J., eds). International life science institute, Washington, DC.

Gamburg, K. Z., E. F. Vysotskaya and L.V. Gamanets (1999): Microtuber formation in micropropagated Jerusalem artichoke (Helianthus tuberosus). Plant Cell, Tissue and Organ Culture, 55: 115-118.

Garner, N. and J. Blake (1989): The induction and development of potato microtubers in vitro on media free of growth regulating substances. Ann. Bot. 63: 663-674.

Gibson, G. R., E. R. Bear, X. Wang, and J. H. Cummings (1995): Selective stimulation of Bifidobacteria in the human colon by oligofructose and inulin. Gastroenterology. 108: 975-982.

Hergert, G. B. (1991): The Jerusalem artichoke situation in Canada. Alternative Crops Notebook. 5: 16-19.

Kays, S. J. and Nottingham, S. F. (2008a): Biology and chemistry of Jerusalem artichoke. CRC Press Taylor \& Francis Group.

Kays, S. J. and S. F. Nottingham (2008b): Classification, Identification, and Distribution. [In: Biology and chemistry of Jerusalem artichoke Helianthus tuberosus L.] CRC Press Taylor \& Francis Group, pp: 29-34.

Kays, S. J. and S. F. Nottingham (2008c): Introduction: An underutilized resource. [In: Biology and chemistry of Jerusalem artichoke Helianthus tuberosus L.] CRC Press Taylor \& Francis Group, pp: 1-6.

Knittel, N., A. Escandon, and G. Hahne (1991): Plant regeneration at high frequency from mature sunflower cotyledons. Plant Science 73: 219-226.

Koda, Y. and Y. Kikuta (1991): Possible involvement of jasmonic acid in tuberization of yam plants. Plant Cell Physiol. 32: 629-633.

Melis, R. J. M and van Staden (1984): Tuberization and hormones. Z. Pflanzenphysiol. 113: 271-283.

Monti A, Amaducci MT, Venturi G (2005): Growth response, leaf gas exchange and fructans accumulation of Jerusalem artichoke (Helianthus tuberosus L.) as affected by different water regimes. Eur.J. Agron., 23 (2): 136-145.

Ng, S. Y. C. (1992): Micropropagation of white yam (Dioscorea rotundata Poir.). [In: Bajaj YPS (ed) Biotechnology in Agriculture and Forestry,] Vol. 19: 135-159. Springer Verlag, Berlin.

Norcini, J. G. and J. H. Aldrich (2000): Cutting propagation and container production of 'Flora Sun' beach sunflower, J. Environ. Hort., 18: 185-187.

Nowak, J. and D. Colborne (1989): In vitro tuberization and proteins as indicators of heat stress tolerance in potato. Amer. Potato J. 66: 35-45.

Paterson, K. and Everett, N. (1985): Regeneration of Helianthus annuus inbred plant from callus. Plant Science 42:125-132. 
Pelissier, B., Bouchefra, O., Pepin, R. and Freyssinet, G. (1990): Production of isolated somatic embryos from sunflower thin cell layer. Plant Cell Rep. 9: 47-50.

Phillips, H. R. (1985): Growing and Propagating Wild Flowers, University of North Carolina Press, Chapel Hill, NC.

Sarrafi, A., J. Roustan, and G. Fallot (1996): Genetic analysis of organogenesis in the cotyledons of zygotic embryos of sunflower (Helianthus annuus L.) Theor. Appl. Genet. 92: 225229.

Seiler. G. J. (1993): Forage and tuber yields and digestibility of selected wild and cultivated genotypes of Jerusalem artichoke. Agron. J. 85: 29-33.

Splittstoesser, W.E. (1990 ) Vegetable Growing Handbook AVI New-York 362.

Swanton, C. (1986): Ecological Aspects of Growth and Development of Jerusalem artichoke (Helianthus tuberosus L.), Ph.D. thesis, University of Western Ontario, Ontario.

Taha, H. S., A. M. El-sawy and S. A. Bekheet (2007): In Vitro Studies on Jerusalem artichoke (Helianthus tuberosus) and
Enhancement of Inulin Production. Journal of Applied Sciences Research, 3 (9): 853-858.

Tassoni A, Bagni N, Ferri M, Franceschetti M, Khomutov A, Marques MP, Fiuza SM, Simonian AR, Serafini FD (2010): Helianthus tuberosus and polyamine research: Past and recent applications of a classical growth model. Plant Physiol. Bioch., 48 (7): 496-505.

Toxopeus, H. (1991): Improvement of Plant Type and Biomass Productivity of Helianthus tuberosus L., Final Report to the EEC, DGXII.

van de Sande Bakhuyzen, H. L. and W.G. Wittenrood (1950): Het tot bloei en zaadvorming brengen van topinambourrassen (project 143), Verslag C.I.L.O., over 1949: 137-144.

Vreugdenhil, D and P. C. Struik (1989): An integrated view of the hormonal regulation of tuber formation in potato (Solanum tuberosum) Physiol. Plant. 75: 525-531.

Wissmann, A. M. and B. K. Tripathi (1977): Recherches sur la tuberization de fragments de tiges de topinambour cultives in vitro. C. R. Acad. Sci. (Paris) D285: 1431-1433. 